Prepared in cooperation with the International Joint Commission, International St. Croix River Watershed Board

\title{
A Digital Terrain Model of Bathymetry and Shallow-Zone Bottom-Substrate Classification for Spednic Lake and Estimates of Lake-Level-Dependent Habitat to Support Smallmouth Bass Persistence Modeling
}

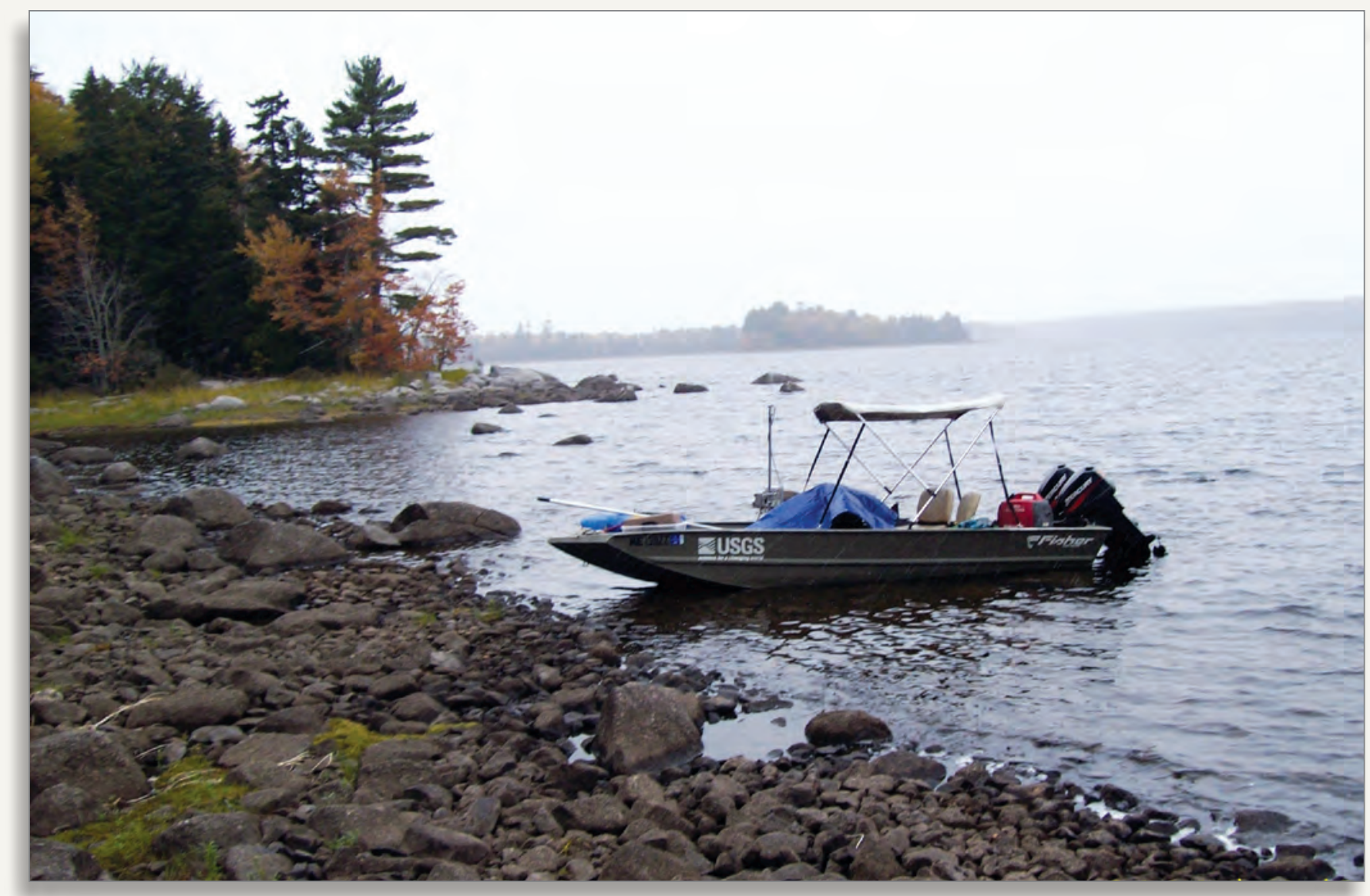

Scientific Investigations Report 2010-5255

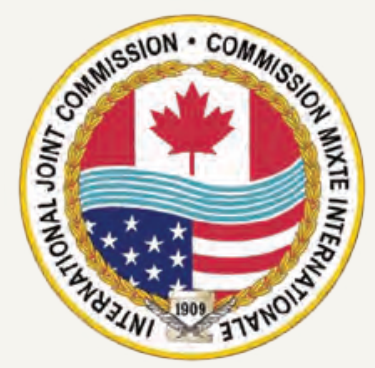


Cover. U.S. Geological Survey boat on the shore of Spednic Lake, November 2009. 


\section{A Digital Terrain Model of Bathymetry and Shallow-Zone Bottom-Substrate Classification for Spednic Lake and Estimates of Lake-Level-Dependent Habitat to Support Smallmouth Bass Persistence Modeling}

By Robert W. Dudley, Charles W. Schalk, Nicholas W. Stasulis, and Joan G. Trial

Prepared in cooperation with the International Joint Commission, International St. Croix River Watershed Board

Scientific Investigations Report 2010-5255 


\title{
U.S. Department of the Interior \\ KEN SALAZAR, Secretary \\ U.S. Geological Survey \\ Marcia K. McNutt, Director
}

\section{U.S. Geological Survey, Reston, Virginia: 2011}

\author{
For more information on the USGS — the Federal source for science about the Earth, its natural and living resources, \\ natural hazards, and the environment, visit http://www.usgs.gov or call 1-888-ASK-USGS \\ For an overview of USGS information products, including maps, imagery, and publications, \\ visit http://www.usgs.gov/pubprod \\ To order this and other USGS information products, visit http://store.usgs.gov
}

\begin{abstract}
Any use of trade, product, or firm names is for descriptive purposes only and does not imply endorsement by the U.S. Government.

Although this report is in the public domain, permission must be secured from the individual copyright owners to reproduce any copyrighted materials contained within this report.
\end{abstract}

Suggested citation:

Dudley, R.W., Schalk, C.W., Stasulis, N.W., and Trial, J.G., 2011, A digital terrain model of bathymetry and shallow-zone bottom-substrate classification for Spednic Lake and estimates of lake-level-dependent habitat to support smallmouth bass persistence modeling: U.S. Geological Survey Scientific Investigations Report 2010-5255, $18 \mathrm{p}$. 


\section{Acknowledgments}

The authors thank Mike Laitta, International Joint Commission, Dan Walters, U.S. Geological Survey, Laura Flight, U.S. Geological Survey, Rory Saunders, National Oceanic and Atmospheric Administration, Jon Hortness, U.S. Geological Survey, Lee Sochasky, St. Croix International Waterway Commission, Lance Wheaton, Maine Guide, Larry Day, proprietor Palfrey Lake Lodge, Peter Cronin, New Brunswick Department of Natural Resources, Fred Kircheis, Maine Atlantic Salmon Commission - retired, and Richard Jordan, Maine Department of Inland Fisheries and Wildlife - retired, for their valuable input and assistance with this project. 



\section{Contents}

Abstract
Introduction
Purpose and Scope
Description of Spednic Lake
$\quad$ Hydrography
Surficial Geologyate
Methods of Study
Data Collection
Post-Processing of Echosounder Data
Post-Processing of ADCP Data
Interpretation of Bottom-Substrate Types
Bathymetry and Shallow-Zone Bottom-Substrate Classification for Spednic Lake
and Estimates of Lake-Level-Dependent Habitat

\section{Figures}

1-3. Maps showing:

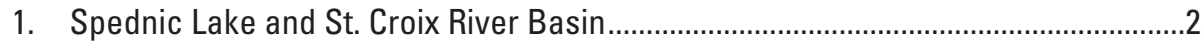

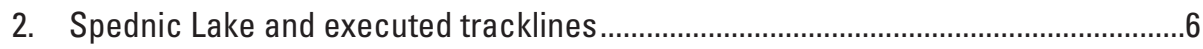

3. Acoustic data points (tracklines) for Spednic Lake..................................................7

4. Graphs showing, $A$, linear regression used to normalize intensity as a function of depth and $B$, plot of residuals....................................................................

5. Flowchart illustrating the logistic classification process ...............................................10

6-8. Maps showing:

6. Point-classifications of sediment types in Spednic Lake .........................................11

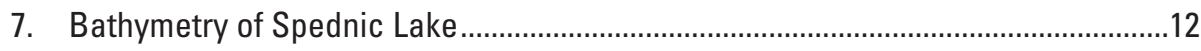

8. Sediment-types of Spednic Lake .......................................................................13

9. Time series plot of $A$, lake level range and $B, C$, annual historical quantities of habitat during the spawning period (May 20-June 20) in Spednic Lake, 1970-2009.

\section{Tables}

1. Annual historical quantities of habitat in Spednic Lake, 1970-2009. 


\section{Conversion Factors}

SI to Inch/Pound

\begin{tabular}{lll}
\hline \multicolumn{1}{c}{ Multiply } & By & \multicolumn{1}{c}{ To obtain } \\
\hline centimeter $(\mathrm{cm})$ & Length & inch (in.) \\
millimeter $(\mathrm{mm})$ & 0.3937 & inch (in.) \\
meter $(\mathrm{m})$ & 0.03937 & foot (ft) \\
kilometer $(\mathrm{km})$ & 3.281 & mile (mi) \\
kilometer $(\mathrm{km})$ & 0.6214 & mile, nautical $(\mathrm{nmi})$ \\
meter $(\mathrm{m})$ & 0.5400 & yard $(\mathrm{yd})$ \\
\hline & 1.094 & \\
hectare $(\mathrm{ha})$ & Area & acre \\
square kilometer $\left(\mathrm{km}^{2}\right)$ & 2.471 & acre \\
square meter $\left(\mathrm{m}^{2}\right)$ & 247.1 & square foot $\left(\mathrm{ft}^{2}\right)$ \\
hectare $($ ha) & 10.76 & square mile $\left(\mathrm{mi}^{2}\right)$ \\
square kilometer $\left(\mathrm{km}^{2}\right)$ & 0.003861 & square mile $\left(\mathrm{mi}^{2}\right)$ \\
\hline & 0.3861 & \\
\hline cubic meter per second $\left(\mathrm{m}^{3} / \mathrm{s}\right)$ & Flow rate & acre-foot per day $(\mathrm{acre}-\mathrm{ft} / \mathrm{d})$ \\
meter per second $(\mathrm{m} / \mathrm{s})$ & 70.07 & foot per second $(\mathrm{ft} / \mathrm{s})$ \\
cubic meter per second $\left(\mathrm{m}^{3} / \mathrm{s}\right)$ & 3.281 & cubic foot per second $\left(\mathrm{ft}^{3} / \mathrm{s}\right)$ \\
millimeter per year $(\mathrm{mm} / \mathrm{yr})$ & 35.31 & inch per year $(\mathrm{in} / \mathrm{yr})$ \\
\hline & 0.03937 & \\
\hline kilopascal $(\mathrm{kPa})$ & Pressure & pound per square inch $\left(\mathrm{lb} / \mathrm{ft}^{2}\right)$ \\
\hline & 0.1450 & \\
\hline
\end{tabular}

Temperature in degrees Celsius $\left({ }^{\circ} \mathrm{C}\right)$ may be converted to degrees Fahrenheit $\left({ }^{\circ} \mathrm{F}\right)$ as follows:

${ }^{\circ} \mathrm{F}=\left(1.8 \times^{\circ} \mathrm{C}\right)+32$

Vertical coordinate information is referenced to the North American Vertical Datum of 1988 (NAVD 88).

Horizontal coordinate information is referenced to the North American Datum of 1983 (NAD 83). 


\title{
A Digital Terrain Model of Bathymetry and Shallow-Zone Bottom-Substrate Classification for Spednic Lake and Estimates of Lake-Level-Dependent Habitat to Support Smallmouth Bass Persistence Modeling
}

\author{
By Robert W. Dudley', Charles W. Schalk', Nicholas W. Stasulis', and Joan G. Trial ${ }^{2}$
}

\section{Abstract}

In 2009, the U.S. Geological Survey entered into a cooperative agreement with the International Joint Commission, St. Croix River Board to do an analysis of historical smallmouth bass habitat as a function of lake level for Spednic Lake in an effort to quantify the effects, if any, of historical lakelevel management and meteorological conditions (from 1970 to 2009) on smallmouth bass year-class failure. The analysis requires estimating habitat availability as a function of lake level during spawning periods from 1970 to 2009, which is documented in this report. Field work was done from October 19 to 23, and from November 2 to 10, 2009, to acquire acoustic bathymetric (depth) data and acoustic data indicating the character of the surficial lake-bottom sediments. Historical lake-level data during smallmouth bass spawning (May-June) were applied to the bathymetric and surficial-sediment type data sets to produce annual historic estimates of smallmouthbass-spawning-habitat area. Results show that minimum lake level during the spawning period explained most of the variability $\left(\mathrm{R}^{2}=0.89\right)$ in available spawning habitat for nearshore areas of shallow slope (less than 10 degrees) on the basis of linear correlation. The change in lake level during the spawning period explained most of the variability $\left(\mathrm{R}^{2}=0.90\right)$ in available spawning habitat for areas of steeper slopes (10 to 40 degrees) on the basis of linear correlation. The next step in modeling historic smallmouth bass year-class persistence is to combine this analysis of the effects of lake-level management on habitat availability with meteorological conditions.

\section{Introduction}

Spednic Lake is a large, undeveloped lake on the United States-Canadian border in the headwaters of the St. Croix River Basin (fig. 1); the lake straddles the international border comprising the eastern border of the State of Maine and the western border of the province of New Brunswick. Spednic Lake is renowned for its smallmouth bass and landlocked salmon fishery (New England Forestry Foundation, 2010; Maine Department of Inland Fisheries and Wildlife, 2010).

The smallmouth bass (Micropterus dolomieu) population (likely introduced sometime before 1900) precipitously declined around the early 1980s. The cause of the population decline is disputed and may have been a result of the presence of alewife (Alosa psuedoharengus), lake-level management, and (or) recreational fishing. In response to the smallmouth bass population decline, alewives were denied access to the lake, and lake-level and fishery management practices were altered. In May 1995, the Maine State Legislature passed a bill to prevent alewife migration in the St. Croix River, thereby elevating the alewife access issue to international importance. The smallmouth bass population has since rebounded and is presently (2010) supporting an active bass fishery (Maine Department of Inland Fisheries and Wildlife, 2010; International Joint Commission, 2005).

The International Joint Commission (IJC) was formed in 1912 as a result of the Boundary Waters Treaty Act (effective 1910). The IJC was invested with the authority to regulate flows and water levels for United States-Canadian boundary waters, which include the St. Croix River (Flagg, 2007). The IJC created the International St. Croix River Board (ISCRB) to supervise compliance with IJC Orders of Approval that guide the regulation of flows and water levels at hydraulic structures in the St. Croix Basin. In 2007, the Board was renamed the International St. Croix River Watershed Board, reflecting the watersheds-based approach of the IJC's International Watersheds Initiative. As part of its responsibilities, the ISCRWB keeps the IJC informed about transboundary issues relating to the ecological health of the St. Croix River. The ISCRWB has identified information gaps and has recommended studies that would develop information to help fishery managers in both countries resolve the alewife access issue (International Joint Commission, 2005).

${ }^{1}$ U.S. Geological Survey

${ }^{2}$ Maine Department of Marine Resources, Bureau of Sea Run Fisheries and Habitat 


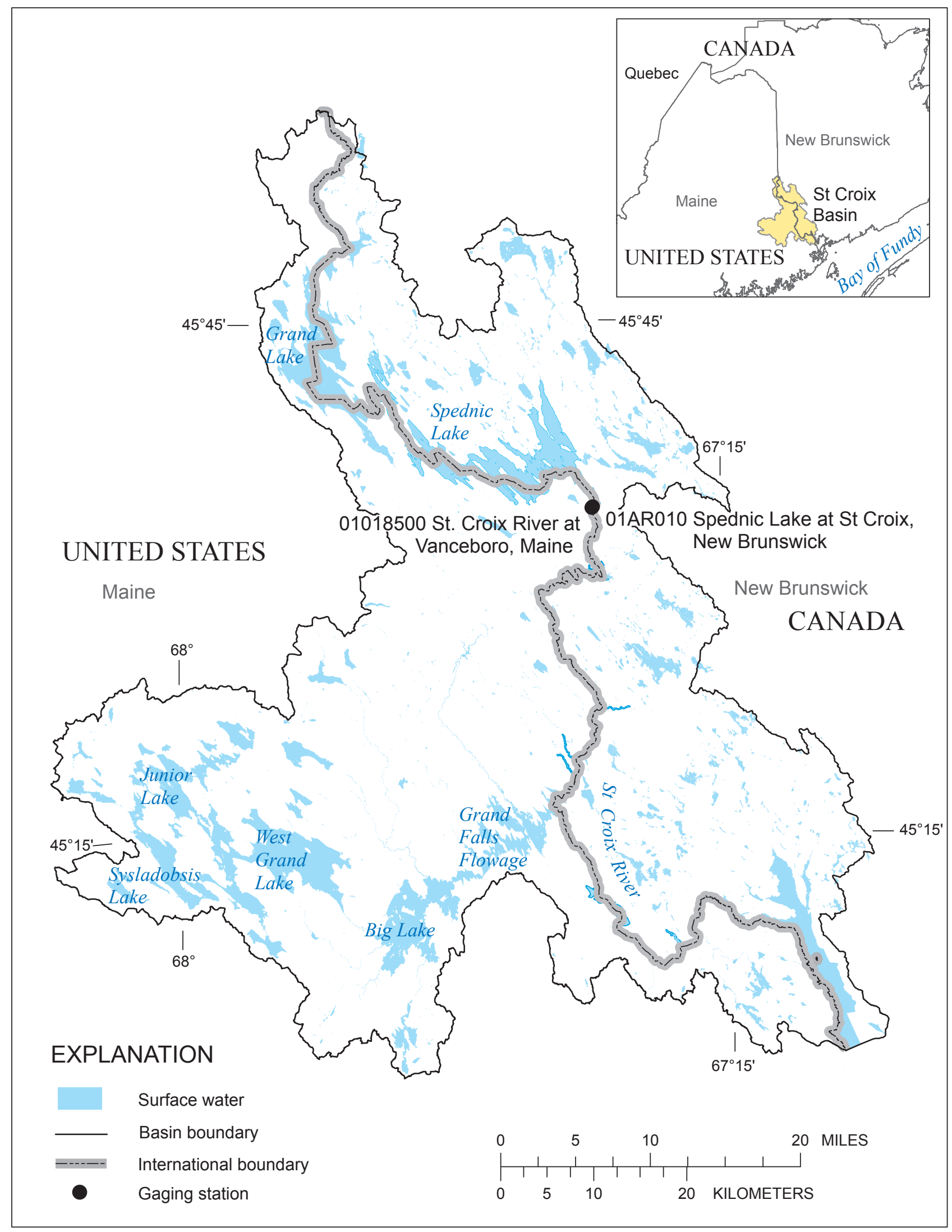

Base from U.S. Geological Survey digital files, 1:24,000 scale, Universal Transverse Mercator projection, zone 19

Figure 1. Spednic Lake and St. Croix River Basin. 
In 2009, the U.S. Geological Survey (USGS) entered into a cooperative agreement with the IJC to do an analysis of historical smallmouth bass spawning habitat as a function of lake level (lake water-surface elevation) for Spednic Lake in an effort to quantify the effects, if any, of historical lake-level management and meteorological conditions (from 1970 to 2009) on the survival of smallmouth bass in the first summer of life. Study objectives included: deriving lake-level smallmouth bass habitat area curves; quantifying available smallmouth bass habitat using bathymetry and bottom character data; evaluating meteorological conditions (specifically temperature) during smallmouth bass spawning (May 20 to June 20), by year, for the historical period 1970 to 2009; and predicting the effects of spawning habitat availability and thermal conditions on survival of smallmouth bass in the first summer of life (May to August) for the same historical period.

\section{Purpose and Scope}

The purpose of this report is to document the data and methods for deriving smallmouth bass spawning habitat area curves and quantifying habitat as a function of lake level. Estimating habitat availability as a function of lake level requires acoustic bathymetric (depth) data and acoustic data indicating the character of the surficial lake-bottom sediments. This report describes the collection of acoustic echosounder and Doppler current profiler (ADCP) data and documents the processes used to check the quality of and analyze these data. The analyses yielded bathymetric and surficial lake-bottom sediment data sets suitable for building a digital terrain model (DTM) of the bathymetry and a map of the spatial distribution of surficial-sediment types in Spednic Lake. Historical lake-level data during smallmouth bass spawning (May 20 to June 20) were used to filter the bathymetric and surficial-sediment type data based on depth, substrate, and slope to produce annual estimates of smallmouth bass spawning habitat area.

\section{Description of Spednic Lake}

\section{Hydrography}

Spednic Lake has a surface area of about 6,970 hectares (ha) and about 170 kilometers $(\mathrm{km})$ of shoreline and is part of the St. Croix River Basin (fig. 1; University of Maine, 2010a). Outflow from the lake into the St. Croix River is controlled by a dam at Vanceboro. The dam was originally a timber crib structure built in 1836 that raised the natural lake level 4.6 meters (m); the dam was replaced in 1965 with a concrete structure outfitted with two tainter gates capable of controlling lake level over a range of $4.38 \mathrm{~m}$ (Flagg, 2007). Lake level at the dam has been gaged by the Water Survey of Canada at station 01AR010 from January 19, 1967, to the present (2010). Mean lake level for the period of record ending December 31, 2008, was $116.27 \mathrm{~m}$; the minimum recorded lake level was $113.89 \mathrm{~m}$ on February 10, 2002; the highest recorded lake level was 117.77 m on May 1, 1973 (Environment Canada, 2010).

Flow in the St. Croix River at Vanceboro has been gaged by USGS streamflow-gaging station 01018500 , maintained by the United States under agreement with Canada and currently operated in cooperation with the IJC from October 22, 1928, to the present (2010). Gaging an upstream drainage area of 1,070 square kilometers $\left(\mathrm{km}^{2}\right)$, the gage has measured monthly mean flows ranging from 13.4 cubic meters per second $\left(\mathrm{m}^{3} / \mathrm{s}\right)$ (November) to $27.8 \mathrm{~m}^{3} / \mathrm{s}$ (May), and mean annual streamflow of $20.6 \mathrm{~m}^{3} / \mathrm{s}$ for the period of record ending September 30, 2009 (U.S. Geological Survey, 2010a). The minimum recorded daily mean flow was $0.05 \mathrm{~m}^{3} / \mathrm{s}$ on October 12, 22, and November 4, 1936, when the flow was held back by a cofferdam to facilitate dam repairs; the highest recorded daily mean flow was $191.6 \mathrm{~m}^{3} / \mathrm{s}$ on June 3, 1984 (U.S. Geological Survey, 2010b).

\section{Surficial Geology}

Spednic Lake lies in a region glaciated until approximately 11,000 to 13,000 years ago when the glacial ice retreated in a pattern generally parallel to the present-day coastline of Maine and New Brunswick (Randall, 2001; Hunter and Smith, 2001). This hydrophysiographic region is characterized by moderate to low relief, with commonly small or shallow closely spaced valleys, and coarse-stratified drift sparsely distributed mostly in eskers (Randall, 2001). As a consequence of glacial advance and retreat across this area, most surficial geology in the Spednic Lake region is compact glacial sediment (till) comprised of a heterogeneous mix of sand, silt, clay, stones, and boulders eroded and transported by glacial movement (Thompson and Borns, 1985; Marvinney and Thompson, 2000).

\section{Climate}

The climate of the Spednic Lake Basin is temperate with mild summers and cold winters. The mean annual air temperature at Vanceboro (elevation $128 \mathrm{~m}$ ) from 1971 to 2000 was about 5 degrees Celsius $\left({ }^{\circ} \mathrm{C}\right)$, with mean monthly air temperatures ranging from about $-10{ }^{\circ} \mathrm{C}$ in January to about $19{ }^{\circ} \mathrm{C}$ in July (National Oceanic and Atmospheric Administration, 2002). Mean annual precipitation during the same 30 -year period was approximately 1,120 millimeters $(\mathrm{mm})$, which was fairly evenly distributed throughout the year (National Oceanic and Atmospheric Administration, 2002). Mean annual evapotranspiration (loss of water to the atmosphere by evaporation from the soil and transpiration from plants) from 1951 through 1980 was about $430 \mathrm{~mm}$ (Randall, 1996). Measured mean annual runoff from 1929 through 2009 was about 610 mm (U.S. Geological Survey, 2010b). 


\section{Methods of Study}

The following sections of the report document the collection and interpretation of data used for bathymetric mapping and classifying surficial lake-bottom sediments, and the geographic-information system (GIS) analysis of those data to estimate quantities of smallmouth bass habitat as a function of lake level. Linear correlations were done using the Pearson product-moment correlation coefficient. The limitations of these data and their interpretation also are briefly discussed.

\section{Data Collection}

Publicly available bathymetric data for Spednic Lake were identified and acquired from United States (University of Maine, 2010b) and Canadian sources (Nelda Craig, New Brunswick Department of the Environment, Sciences and Reporting Branch, written commun., 2009). Data from both sources were based on a 1954 survey by the Maine Department of Inland Fisheries and Wildlife. These data were not usable for this study because the elevation of the water surface at the time of the survey was not recorded, and the horizontal positioning of the depth data was estimated, not precisely located. However, the data set did provide coarse quality assurance for bathymetric data collected for this study.

Bathymetric data collection was done from October 19 to 23, and from November 2 to 10, 2009. Data collection was done using a 200 kilohertz $(\mathrm{kHz})$ Navisound 210 echosounder and ADCP operating at $1200 \mathrm{kHz}$, thereby producing two concurrent bathymetric data sets for mutual backup, quality assurance, and to facilitate interpretation of bottom type. The echosounder and ADCP units were used for the bathymetric survey to collect a high density of precisely located depth data in a relatively short period of time. On a few occasions because of logistics or field conditions (extremely shallow conditions and hazardous navigation), only the ADCP was used. Survey tracklines were planned using HYPACK - a hydrographic surveying software package used for data collection and processing of single beam, multibeam, and side-scan sonar data. Echosounder data were logged in HYPACK with time tags and synchronized with a Hemisphere A100 globalpositioning system (GPS) location referenced to State Plane North American Datum of 1983 (NAD 83), ME-1801 Maine East US Survey Foot datum; vertical units equal horizontal units in US Survey Foot. Approximately $332 \mathrm{~km}$ of survey tracklines were run (fig. 2). ADCP data were logged in Teledyne RD Instrument's WinRiver II software with time and synchronized to the identical string of GPS data.

Speed of sound was measured and verified (1,500 meters per second $(\mathrm{m} / \mathrm{s})$ ) using manual tape-downs (a sounding weight affixed to a reel-retractable steel tape), and the echosounder and ADCP were configured to these conditions. The echosounder was configured on the basis of the depth of the transducer in the water and a user-specified value for the speed of sound. The ADCP was configured on the basis of the depth of the transducer in the water and the ADCP computed the speed of sound for each vertical profile on the basis of the water temperature and salinity measured at the transducer face. The ADCP unit also was configured to maximize data collection for interpreting surficial bottom-sediment type to a depth of approximately $5.0 \mathrm{~m}$, though depth readings from the ADCP were collected to a maximum depth of approximately $9.8 \mathrm{~m}$. Interpretation of surficial bottom-sediment type was limited to $5.0 \mathrm{~m}$ to capture the range of depths at which bass spawning habitat was most likely to occur over a range of lake-level elevations.

Manual tape downs, bottom observations, probing, and sampling were done for assembling a data set suitable for interpreting surficial lake-bottom sediment types from the acoustic data (ground truthing), and quality assuring collected bathymetric data. Fifty-seven observations, probes, or samples were done over the course of the survey to document various surficial lake-bottom sediment types. Ten manual tape downs were collocated within $10 \mathrm{~m}$ of echosounder data and 11 manual tape downs were collocated within $10 \mathrm{~m}$ of ADCP data over the course of the survey to confirm that the echosounder and ADCP were reading depths accurately. The mean difference between 10 tape downs and echosounder data was $-0.01 \mathrm{~m}(0.14 \mathrm{~m}$ standard deviation). The mean difference between 11 tape downs and ADCP data was $-0.52 \mathrm{~m}(0.88 \mathrm{~m}$ standard deviation).

Depth data were converted to bottom-elevation data on the basis of lake level as datum. Daily gaged lake-level data were obtained from the Water Survey of Canada (Environment Canada, 2010).

\section{Post-Processing of Echosounder Data}

Field data were loaded into HYPACK software (version 9.0 9.1.0.0) for post-processing. A levels-corrections file was created using the Manual Tides module. The levels correction file was used to convert depth data to bottom elevations on the basis of lake-level time-series data. Echosounder data were post-processed on a transect-by-transect basis using the Single Beam Editor module. Erroneous readings (obviously unrealistic spikes) were censored. Noise was censored from the data using the filter function with spike limit set to 0.2 and gate step set to 2.0. Following censoring, the bottom-elevation data were smoothed using the default 64-sample averaging and output from HYPACK for subsequent GIS processing for bathymetric mapping (fig. 3).

\section{Post-Processing of ADCP Data}

ADCP data were loaded into the Teledyne RD Instruments WinRiver II software for post processing. ADCP data were post-processed on a day-by-day basis. For each day, latitude, longitude, and average depth of the four beams 
were output from WinRiver II; the depth data were adjusted, using a similar levels-correction file as that used for the echosounder post-processing, to convert the ADCP depth data to bottom elevations on the basis of lake-level time-series data. The resulting bottom-elevation data files were imported into GIS for bathymetric mapping (fig. 3). A second output template was created in the WinRiver II software to output all parameters required for interpretation of bottom substrate type. The parameters used for determining bottom substrate are discussed in the section, "Interpretation of Bottom Substrate Type."

\section{GIS Construction of the Digital Terrain Model of Bathymetry}

Echosounder data were the primary bathymetric record; ADCP data were secondary. Echosounder data were used for 91 percent of the transect distance surveyed (302 of $332 \mathrm{~km}$ ); ADCP data were used for the remaining 9 percent ( 30 of $332 \mathrm{~km}$ ) - predominantly in extremely shallow water. The median difference between ADCP and echosounder depths was $+0.08 \mathrm{~m}(\mathrm{~N}=314,272$ depth data points within $0.2 \mathrm{~m}$ along $302 \mathrm{~km}$ of common transect lines). Differences in depths recorded by the echosounder and the ADCP were functions of how the hardware operated. The echosounder measured depths using a single transducer configured vertically while the ADCP measured depth as an average of four different transducers pointed out at 20-degree angles from the vertical; thus, depth readings in areas with a highly irregular bottom (boulders) could vary greatly at any given point between the ADCP and the echosounder. The median difference in depths (echosounder depth - ADCP depth) is $+0.08 \mathrm{~m}$; because the echosounder and ADCP operate using different frequencies, the echosounder acoustic signal likely penetrated muddy sediments deeper than the ADCP acoustic signal, which may explain why the median difference in depths is positive.

The echosounder and ADCP data were 10-percent subsampled because of the high density of data available. The echosounder and ADCP were operated in continuous mode, providing (after initial processing) more than 4.2 million discrete depth points along the $332 \mathrm{~km}$ surveyed, an average of one depth sounding every 8 centimeters $(\mathrm{cm})$. Vertical changes over the average $8-\mathrm{cm}$ interval were usually negligible (less than $0.03 \mathrm{~m}$ ), indicating that many of the data points were superfluous. Consequently, every tenth data point was retained for use in the bathymetric analysis. This subsample provided a good balance between analytical accuracy and computational speed. This subsample was used to create point data with northing, easting, and elevation attributes that were subsequently processed in GIS. Horizontal coordinates were in the Universal Transverse Mercator (UTM) projection, NAD 83. Vertical elevations were measured from the North American Vertical Datum of 1988 (NAVD 88). Surveyed edge points, particularly in areas where accurate orthoimagery of the lake boundary was unavailable, and locations of manual tape downs, bottom observations, probing, and sampling were included in the GIS processing. In all, nearly 434,000 points were used to create the digital terrain model (DTM).

Several data layers were used to constrain the creation of the DTM. Lakeshore boundaries were digitized from 2-m aerial photography dated July 25, 2007, and assigned an elevation equal to the mean lake level on that day, $116.799 \mathrm{~m}$; this was the highest lake level for which good controls were available. Contours on the bathymetric surface were drawn at seven intermediate elevations ranging from $100 \mathrm{~m}$ to $113.4 \mathrm{~m}$ on the basis of the echosounder and ADCP data. Other line features were added to incorporate shallow water observations in areas where the boat could not go.

The maximum historical lake level was $117.77 \mathrm{~m}$, but no aerial imagery of the lake at that elevation was available. To include the near lakeshore land-surface features in the DTM, contours at elevations of $116.8 \mathrm{~m}, 117.6 \mathrm{~m}$, and $118.4 \mathrm{~m}$ were drawn from 30-m digital elevation model (DEM) data. However, because of the coarseness of these DEM data, the contours did not agree with the digitized lakeshore boundary. Consequently, the contours derived from the DEM were manually adjusted to the lakeshore boundary with the intent of preserving the slope, as indicated by the positions of the three contour lines, as near as possible. These land-surface contours, with the point and line features described above, were used to build the DTM of elevation data and a second model of slope data at 9-m resolution. Bottom substrate data, described below, were combined with field observations of the shoreline (everywhere being rock-gravel) to derive polygons of bottom-substrate types.

\section{Interpretation of Bottom-Substrate Types}

Surficial bottom-sediment types were classified using a logistic regression, which used one or more explanatory variables to estimate the discretization of the response variable into two or more nominal response categories. An independent regression was derived for each possible contrast, thus for $n$ response categories, there were $n-1$ logistic regressions derived (Helsel and Hirsch, 2002); for this study, three logistic regression equations defined four surficial bottom-sediment categories.

The logistic regressions were derived on the basis of ADCP and visual sediment category data collected at 38 out of 57 bottom-sediment ground-truth points in areas of the lake less than $5 \mathrm{~m}$ deep. About one-third of the bottom-sediment groundtruth points (the remaining 19 points) were reserved to validate the logistic regressions. The average of the ADCP data at each observation point and 10 readings before and after it along a transect (21 total readings averaged together) was calculated for each of the 38 ground-truth points. Twenty-one readings were used at each ground-truth point to make use of the high density of data in the vicinity of each point and to ensure that the bottom intensity data were representative of the point. 


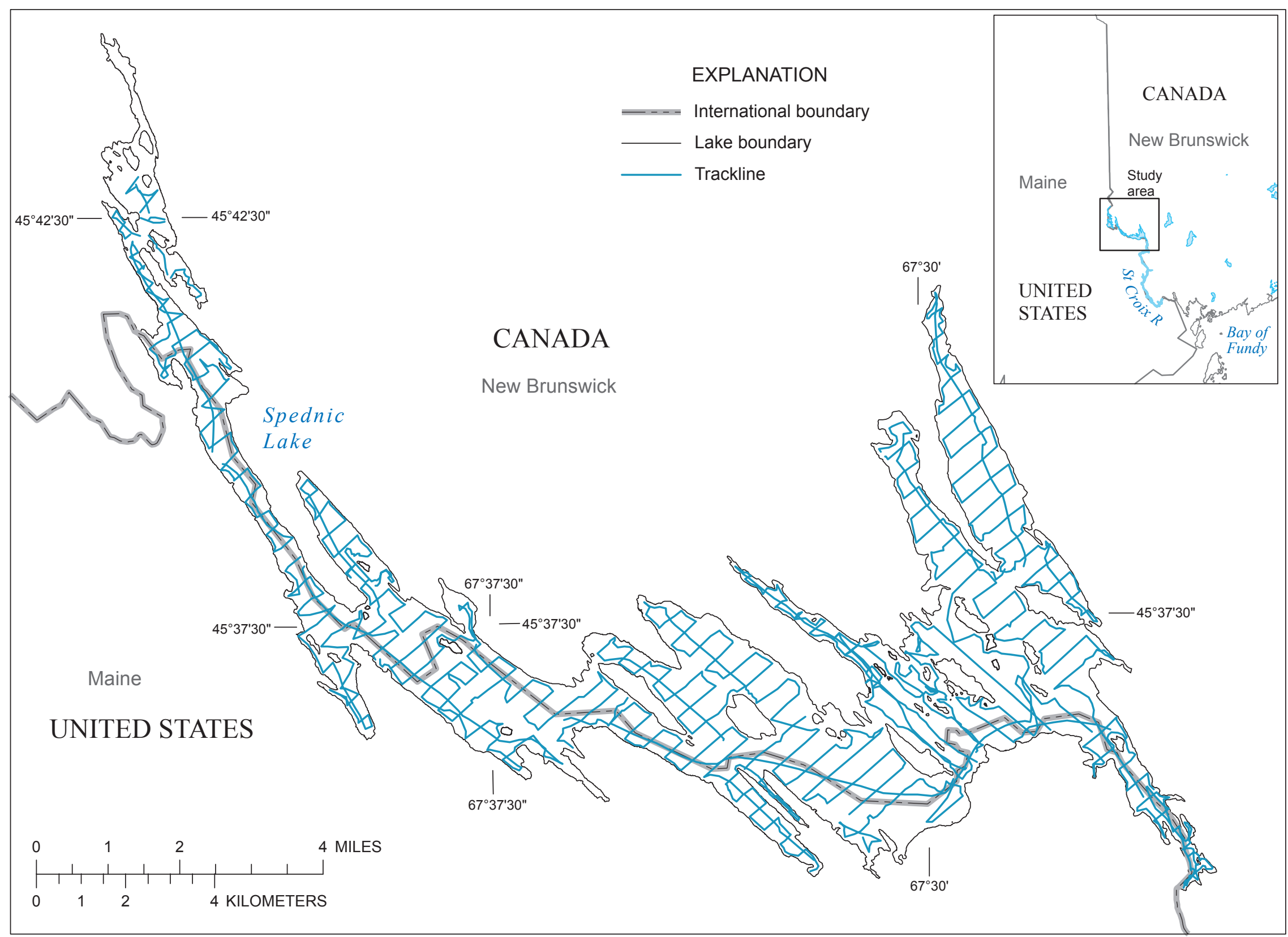

Base from U.S. Geological Survey digital files,

1:24,000 scale, Universal Transverse Mercator

projection, zone 19

Figure 2. Spednic Lake and executed tracklines. 


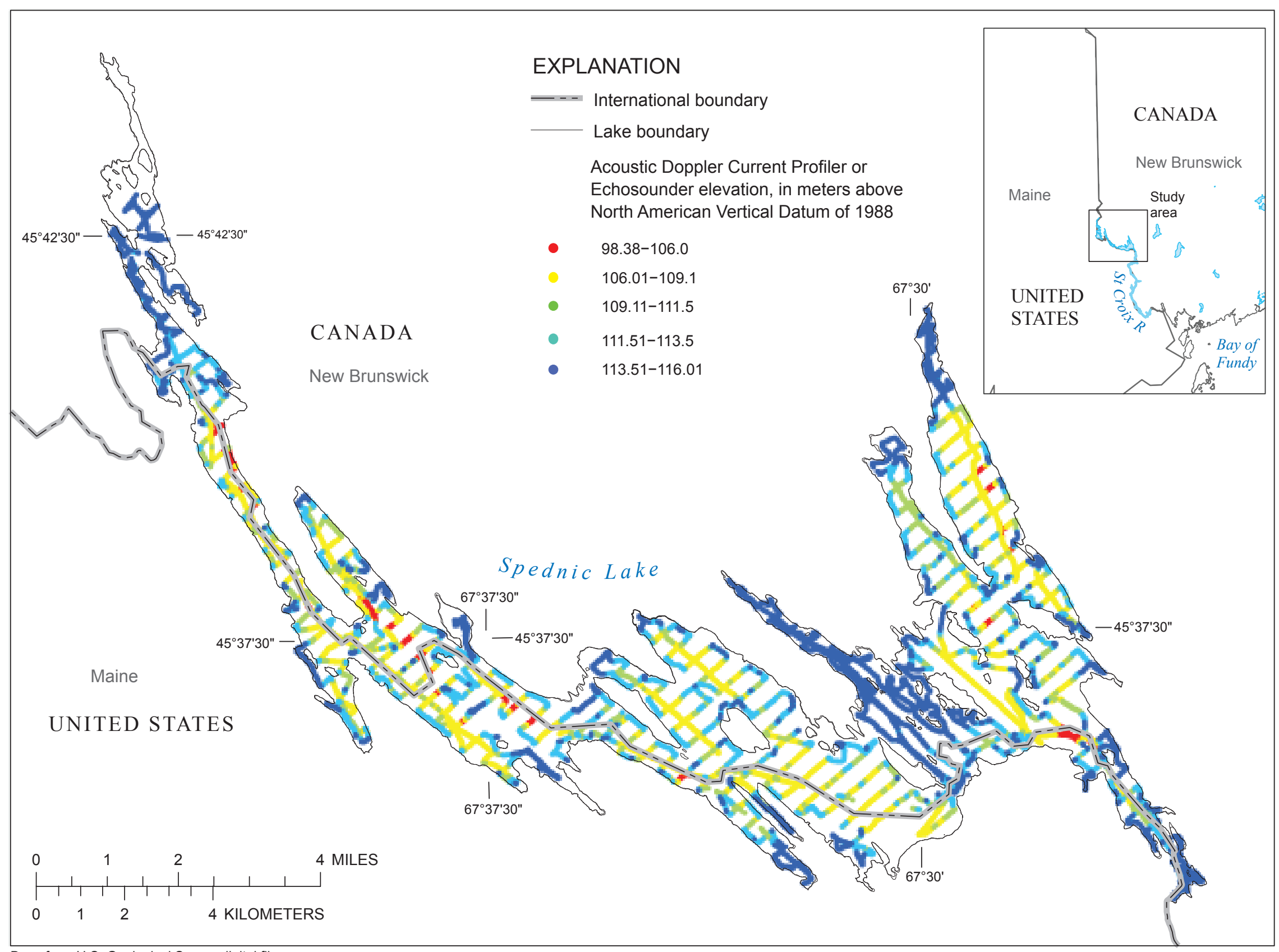

Base from U.S. Geological Survey digital files,

scale 1:24,000, Universal Transverse Mercator

projection, zone 19

Figure 3. Acoustic data points (tracklines) for Spednic Lake. 
The four surficial bottom-sediment categories were:

1. Rocky (R) - The coarsest surficial bottom-sediment types observed in the study area: boulders, bedrock, and large cobbles.

2. Gravelly $(\mathrm{G})$-Coarse surficial bottom-sediment types: small cobbles and sand and gravel

3. Muddy (M) - Fine surficial bottom-sediment types: mud and silt.

4. Vegetated (V) - This classification was included because the acoustic data collected in areas with aquatic vegetation often resembled a rocky bottom type because of irregular acoustic reflections from the vegetation; it was thus necessary to derive specific methods to identify this bottom type to differentiate it from rock. Field observations noted vegetated areas most commonly coincided with muddy or sandy surficial bottomsediment types. In the final classification of surficial bottomsediment types for mapping, all types classified as vegetated (V) were converted to muddy (M).
Because intensity of the reflection of sound from the lake bottom was one of the explanatory variables, it was first necessary to normalize all ADCP intensity readings as a function of depth, because intensities decreased with depth. Average intensity values in the vicinity of the water-sediment interface (lake bottom) were normalized to depth using a linear regression (eq. 1, fig. 4) derived from a 5-percent random sampling of all bottom intensity readings collected over the entire survey in areas less than $5 \mathrm{~m}$ deep $(\mathrm{n}=12,155$ data points). The sample, on the basis of computer-generated random-numbers, represented all days of data collection and yielded a manageable data set with which to derive the normalization regression equation. For the data collected in less than $5 \mathrm{~m}$ of water, a linear relation between depth and intensity seemed to yield a satisfactory regression equation (adjusted coefficient of determination, $\mathrm{R}^{2}=0.09$; $\mathrm{p}$-value less than 0.0001 ; residual standard error: 15.05) evaluated on the basis of linearity and distribution of residuals (Helsel and Hirsch, 1992).
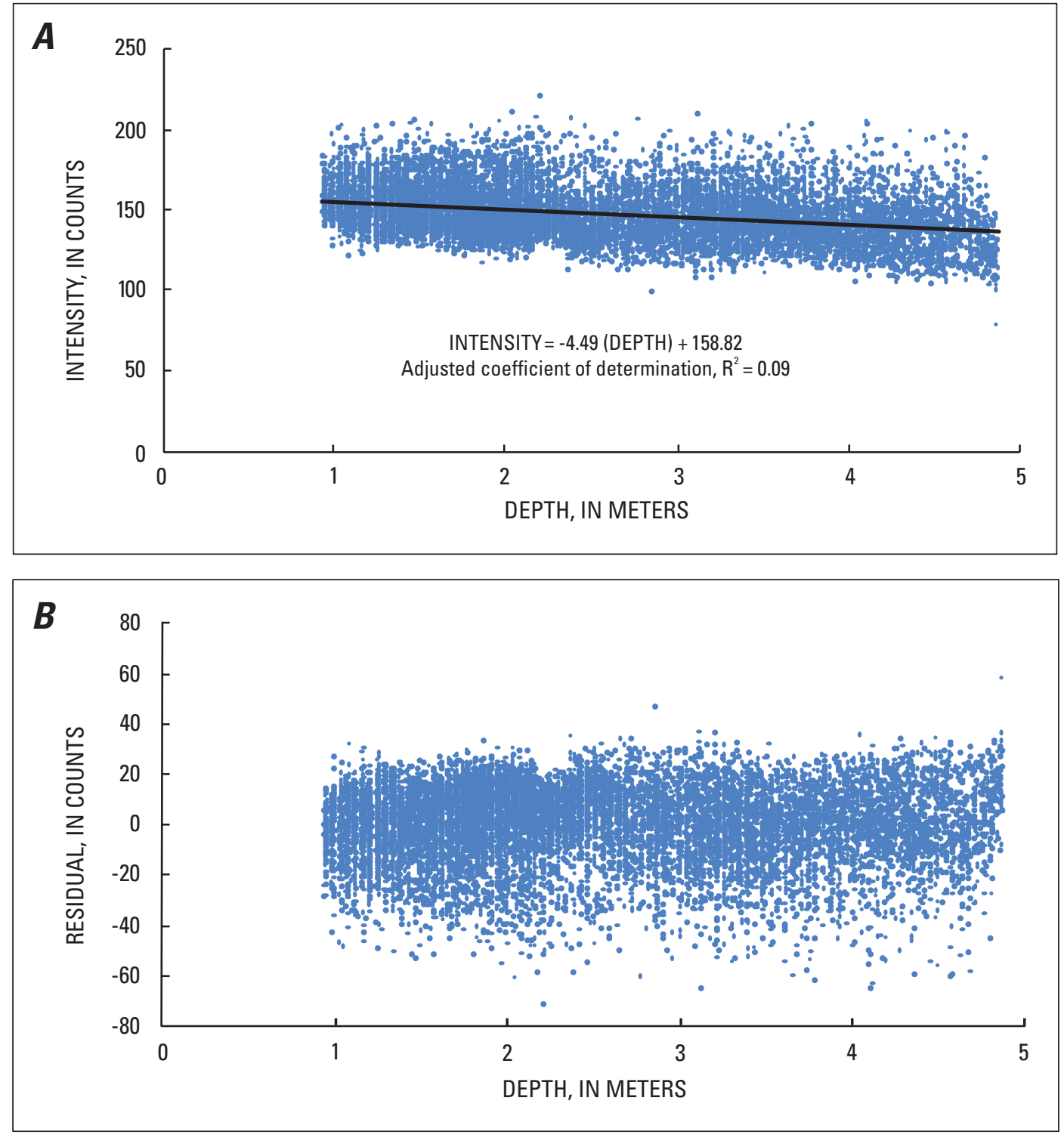

Figure 4. $A$, linear regression used to normalize intensity as a function of depth and $B$, plot of residuals. 


$$
I_{n a}=\frac{I_{a}}{(b-a D)}
$$

where

$I_{\text {na }} \quad$ is the normalized average intensity in the vicinity of the lake bottom (plus or minus $0.40 \mathrm{~m}$ ), in counts;

$I_{\text {a }}$ is the raw ADCP intensity in the vicinity of the lake bottom, in counts;

$D \quad$ is the water depth, in meters; and

$b, a \quad$ are derived regression coefficients.

Following normalization of intensity data as a function of depth, several explanatory variables for deriving logistic regressions were computed from the ADCP record. After evaluating several potential variables, the following had the greatest explanatory power: depth variance (eqs. 2 and 3), average bottom intensity, local bottom variation, and intensity ratio (eq. 4). The depth variance was the computed variance in depth among the four acoustic transducers of the ADCP; a smooth, featureless bottom would have a low variance, and a rocky, irregular bottom would have a high variance. Average bottom intensity was computed as the average bottom intensity from transducer number one in the vicinity of the lake bottom (plus or minus $0.40 \mathrm{~m}$ ). In this case, a single transducer was used for ease of computation and to avoid losing bottom-variation information by averaging four transducers together. Transducer number one was always oriented in the same location on the ADCP unit throughout the survey. Local bottom variation was computed as the difference in depth to the lake bottom from transducer number one between the point of interest and the depth to lake bottom from five prior readings. Thus it was a measure of how quickly the elevation of the lake bottom varied along the transect. The intensity ratio was the ratio of the depth at which the first intensity reading for transducer number one was equal to or greater than 170 counts was encountered, divided by the total depth at the lake bottom. The intensity ratio effectively detected the presence of vegetation, and thus, differentiated between vegetated areas and rocky areas.

where

$$
D_{a}=\frac{\left(D_{1}+D_{2}+D_{3}+D_{4}\right)}{4}
$$

$D_{a} \quad$ is the average depth of the four acoustic transducers of the ADCP, in meters;

$D_{1} \quad$ is the depth from transducer number one, in meters;

$D_{2} \quad$ is the depth from transducer number two, in meters;

$D_{3} \quad$ is the depth from transducer number three, in meters; and

$D_{4} \quad$ is the depth from transducer number four, in meters.

$$
D_{v}=\frac{\left[\left(D_{1}-D a\right)^{2}+\left(D_{2}-D a\right)^{2}+\left(D_{3}-D a\right)^{2}+\left(D_{4}-D a\right)^{2}\right]}{3}
$$

where

$D_{v} \quad$ is the variance in depths recorded by the four acoustic transducers of the ADCP, in square meters.

$$
D_{\text {ratio }}=\frac{D_{0}}{D_{b}}
$$

where

$D_{\text {ratio }} \quad$ is the ratio of the depth at which the first intensity reading equal to or greater than 170 counts is encountered, divided by the depth at the water-sediment interface (lake bottom);

$D_{0} \quad$ is the depth at which the first intensity reading equal to or greater than 170 counts is encountered, in meters; and

$D_{b} \quad$ is the depth at the lake bottom, in meters.

The three derived logistic regressions were linear equations of the form:

$$
z=m\left(D_{v}\right)+n\left(I_{\text {na }}\right)+p(S)+q\left(D_{\text {ratio }}\right)+r
$$

where

$z \quad$ is the logit;

$S$ is a measure of local bottom variation, in meters;

$m, n, p, q \quad$ are derived regression coefficients; and

$r \quad$ is the derived regression intercept.

The logit, z, was input to the logistic function (eq. 6) and yielded a probability, $\mathrm{f}(\mathrm{z})$ (between 0 and 1 ), that the ADCP survey point should be classified into one nominal response category, else it should be classified as another category (fig. 5). The probability cutoff used between classifications was 0.50 .

$$
f(z)=\frac{1}{\left(1+e^{-z}\right)}
$$

The logistic regression equations were applied to all of the ADCP data to differentiate every set of 21 ADCP survey points into nominal response categories in the same fashion they were derived for the ground-truth points; thus every serial group of 21 values averaged together received a nominal classification of either R, G, M, or V (fig. 5). Following this initial classification, a smoothing function was applied to help reduce 

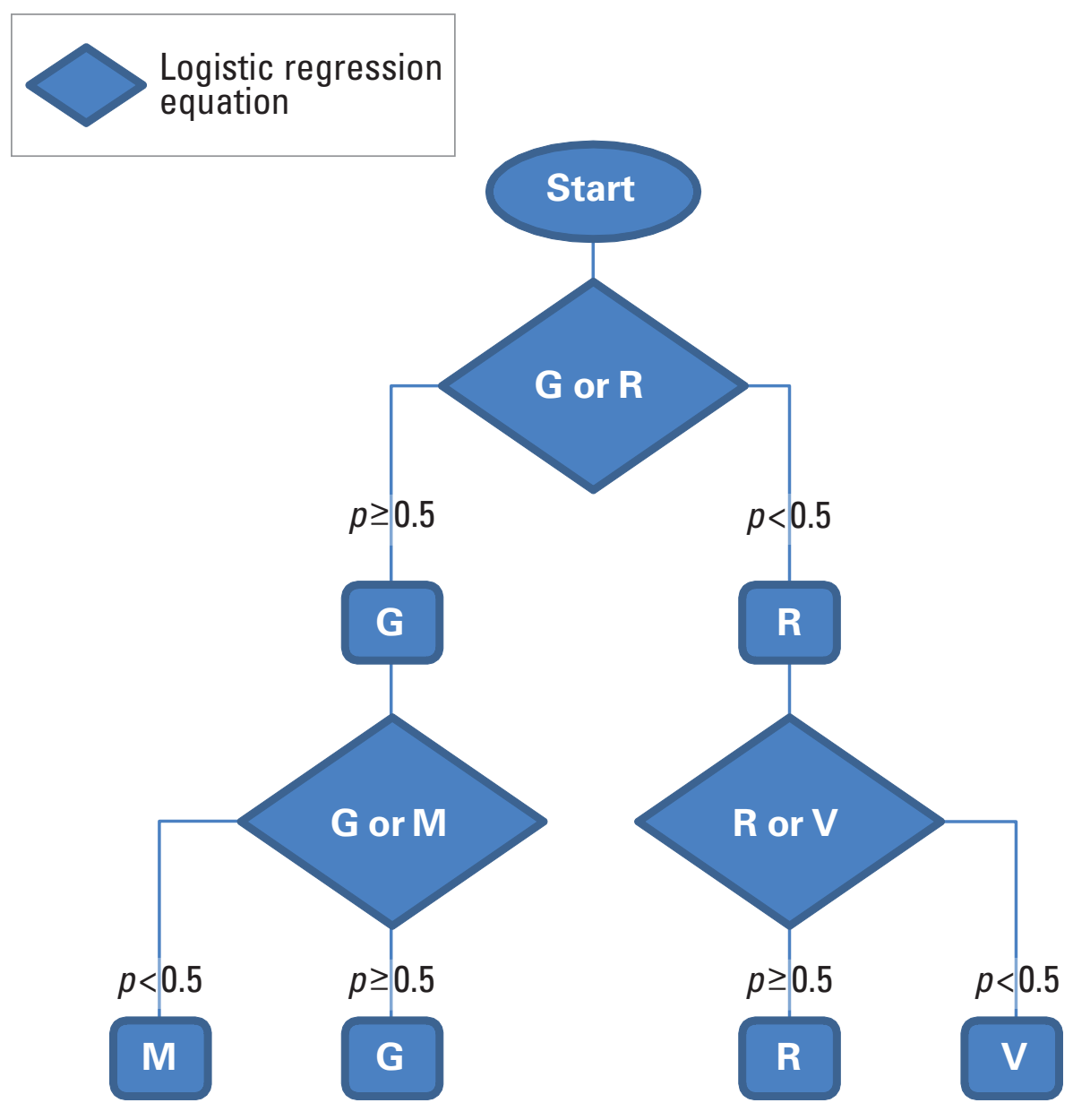

Figure 5. Flowchart illustrating the logistic classification process. [R, rocky; $G$, gravelly; $M$, muddy; $V$, vegetation; $\geq$, greater than or equal to; $<$, less than; ]

possible misidentification errors and produce final dominantsubordinate classification determinations (fig. 6). The smoothing function grouped ADCP points classified above into groups of five and returned a single dominant-subordinate classification point for each group. For example, if a group of five points had four or five ' $R$ ' classifications, it was classified as ' $R$,' but if it had three ' $R$ ' classifications and two ' $G$ ' classifications, it was classified ' $\mathrm{Rg}$ ' — dominant rock, subordinate gravel. In the case of ties, coarser bottom types dominated over finer bottom types. For example, if a group of five points had two 'R'classifications, two ' $G$ ' classifications, and one ' $M$ ' classification, it would be classified as 'Rg.'

Logistic regression classification of surficial bottomsediment types compared favorably with the observed bottom types. Of the 19 observations reserved to validate the accuracy of the classification scheme, 74 percent were correctly classified, 5 percent were incorrectly classified, and 21 percent were inconclusive because the observed bottom type could not be definitively classified.

\section{Bathymetry and Shallow-Zone Bottom-Substrate Classification for Spednic Lake and Estimates of Lake-Level-Dependent Habitat}

The digital terrain model derived for Spednic Lake provided the data used to estimate smallmouth bass spawning habitat on the basis of depth (fig. 7), and sediment type (fig. 8), for two slope classifications. Smallmouth bass spawning habitat depends on lake level during the spawning period (May 20 to June 20) and was defined using the following criteria: surficial bottom-sediment dominated by cobble, boulder or gravel (bottom-type classifications Rg, G, Gr, and Gm), and depths from 1 to $3 \mathrm{~m}$ (Clark and others, 1998; Clark and others, 2008; Saunders and others, 2002; Rejwan and others, 1999). Habitat area was then determined for two bottom slope classifications (less than 10 degrees and 10 to 40 degrees). 


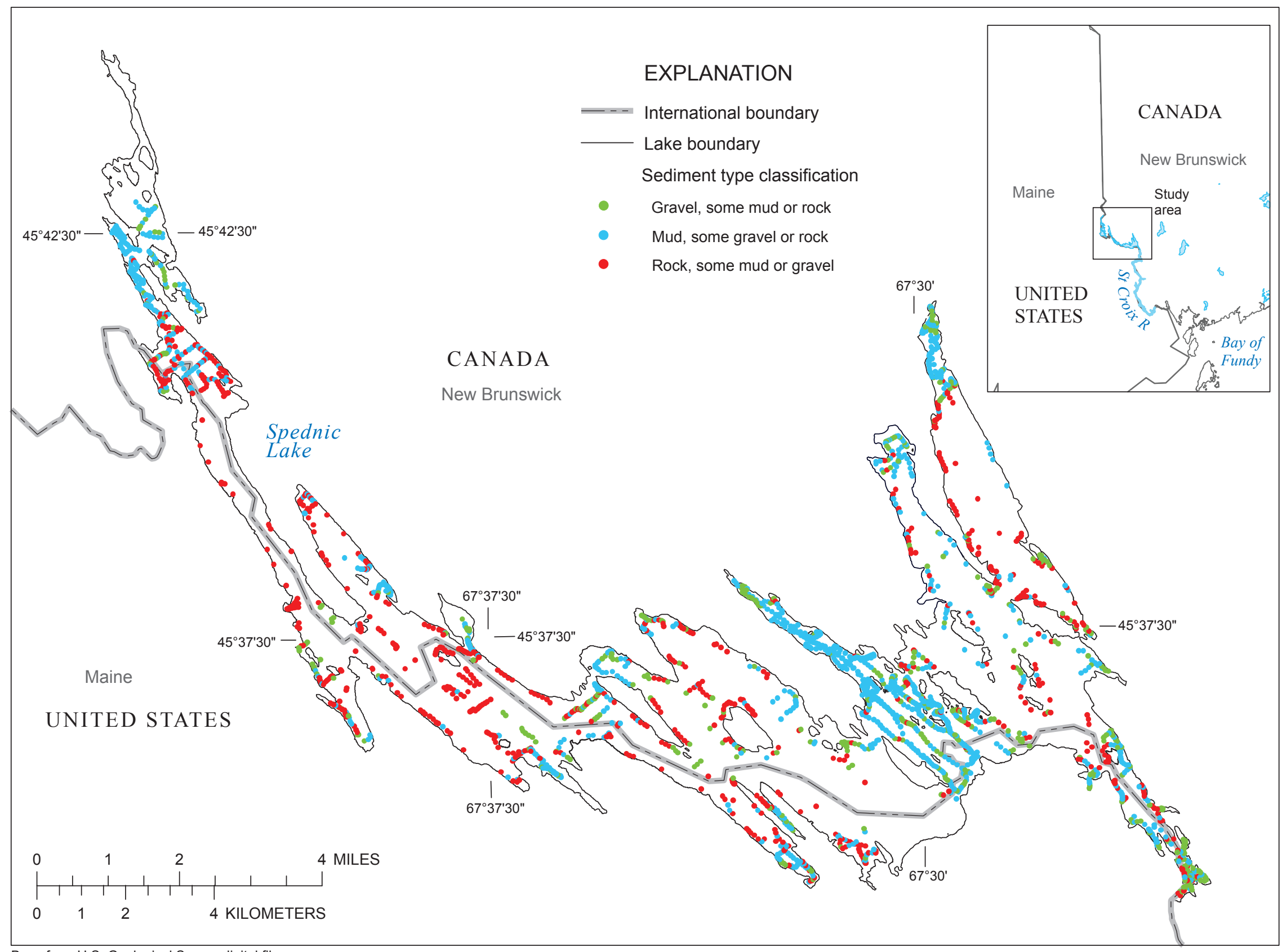

Base from U.S. Geological Survey digital files,

scale 1:24,000, Universal Transverse Mercator

projection, zone 19

Figure 6. Map of Spednic Lake showing the point-classifications of sediment types 


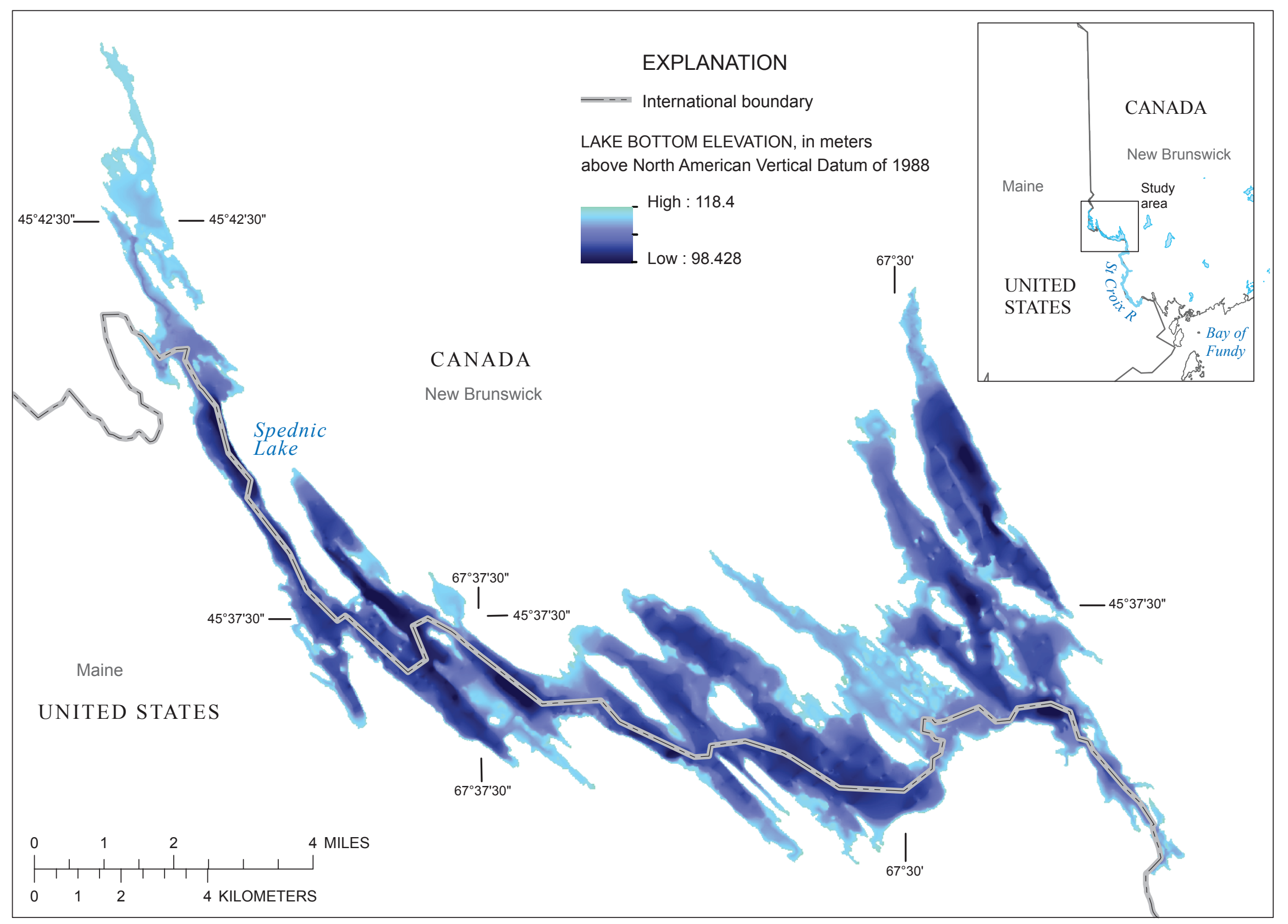

Base from U.S. Geological Survey digital files,

scale 1:24,000, Universal Transverse Mercator

projection, zone 19

Figure 7. Bathymetric map of Spednic Lake. 


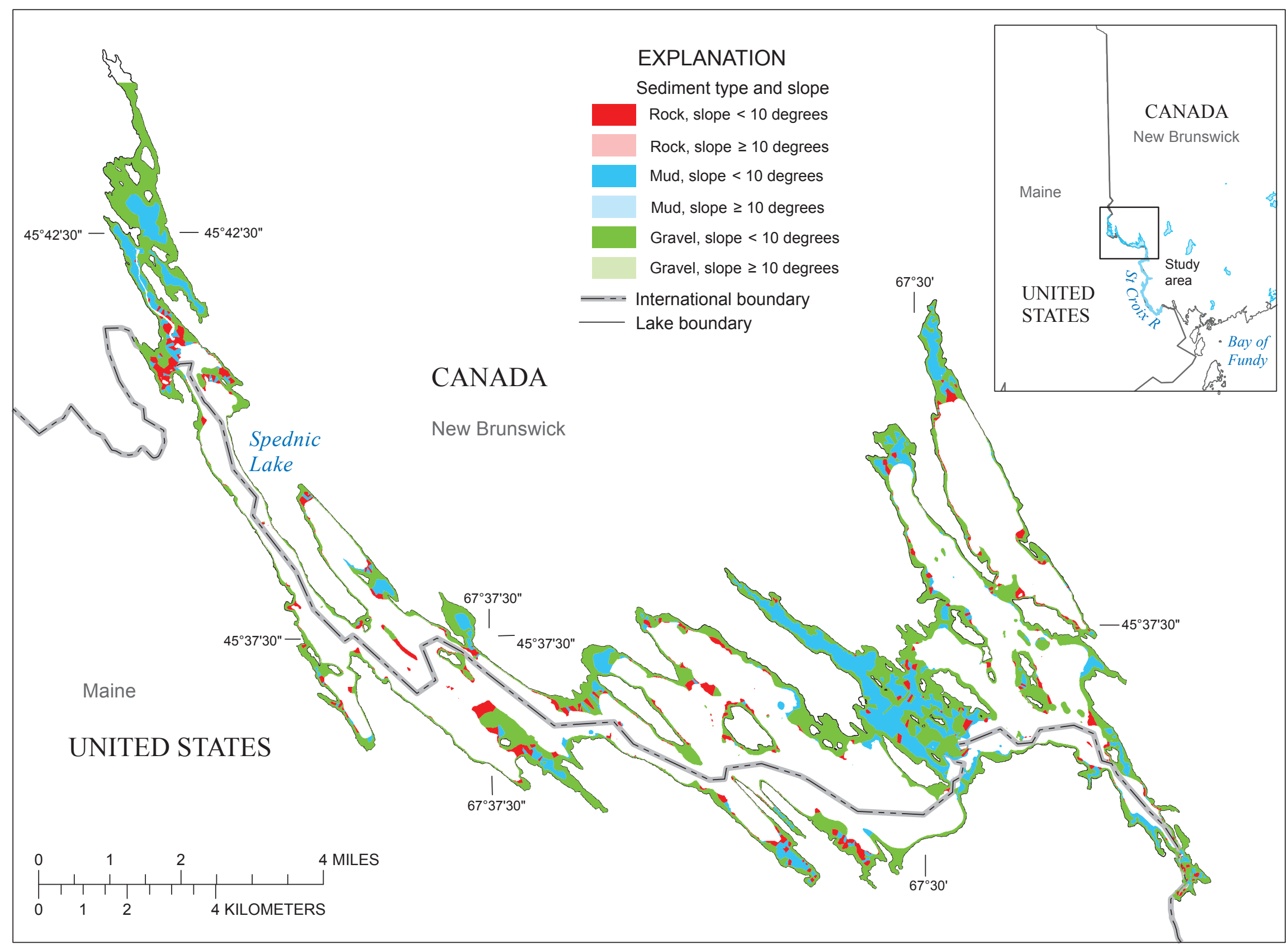

Base from U.S. Geological Survey digital files, scale 1:24,000, Universal Transverse Mercator

projection, zone 19

Figure 8. Sediment-type map of Spednic Lake. 


\section{Digital Bathymetry and Substrate Classification for Spednic Lake and Estimates of Smallmouth Bass Habitat}

The bathymetric data and criteria were used to identify areas of suitable habitat during the bass nesting season (May 20 - June 20) on an annual basis from 1970 to 2009. The most important filter was to determine the areas covered with 1 to $3 \mathrm{~m}$ of water for the entire spawning season. For every year, 1- and 3-m depths from the minimum and maximum lake levels were used to create inundation areas. The areas that met the 1- and 3-m criteria for the maximum lake level were intersected with the areas that met the 1- and 3-m criteria for the minimum lake level; from these inundated areas, the sum of area with suitable bottom substrate were classified by slope to estimate the location and amount of annually available habitat suitable for bass spawning (table 1, fig. 9).

Minimum lake level during the spawning period explained most of the variability $\left(\mathrm{R}^{2}=0.89\right)$ in available spawning habitat for the less-than-10-degree slope category on the basis of linear correlation (fig. 9). Habitat in the less-than-10-degree slope category composes most of the near-shore areas of the lake (fig. 8). The change in lake level during the spawning period explained most of the variability $\left(\mathrm{R}^{2}=0.90\right)$ in available spawning habitat for the 10 - to 40-degree slope category on the basis of linear correlation (fig. 9). The assumption is that the availability of bass spawning habitat has the potential to limit the number of nest sites and thus the production of young bass. Poor survival of smallmouth bass in their first growing season has been linked to changes in water level (Ploskey and others, 1996; Neves, 1975; Clark and others, 1998) and temperature (Shuter and others, 1980, 1985; Finlay and others, 2001; Goff, 1985; MacLean and others, 1981). Thus, the next step in modeling historic smallmouth bass reproductive success is to combine this analysis of the effects of lake-level management on habitat availability with meteorological conditions (from 1970 to 2009). 
Table 1. Annual historical quantities of habitat in Spednic Lake, 1970-2009.

\begin{tabular}{|c|c|c|c|c|}
\hline \multirow[b]{2}{*}{ Year } & \multicolumn{2}{|c|}{ Lake level during spawning period, in meters } & \multicolumn{2}{|c|}{ Habitat area during spawning period, in hectares } \\
\hline & Maximum & Minimum & $\begin{array}{c}\text { Bottom slope } \\
\text { less than } 10 \text { degrees }\end{array}$ & $\begin{array}{c}\text { Bottom slope } \\
\text { from } 10 \text { to } 40 \text { degrees }\end{array}$ \\
\hline 1970 & 117.55 & 117.05 & 883 & 12.7 \\
\hline 1971 & 117.32 & 117.00 & 868 & 14.0 \\
\hline 1972 & 117.56 & 117.38 & 1,170 & 15.3 \\
\hline 1973 & 117.54 & 117.21 & 1,010 & 14.1 \\
\hline 1974 & 117.56 & 117.45 & 1,200 & 15.8 \\
\hline 1975 & 117.46 & 117.19 & 1,010 & 14.6 \\
\hline 1976 & 117.58 & 117.40 & 1,170 & 15.3 \\
\hline 1977 & 117.57 & 117.17 & 967 & 13.5 \\
\hline 1978 & 117.43 & 116.49 & 373 & 8.8 \\
\hline 1979 & 117.55 & 117.30 & 1,110 & 14.8 \\
\hline 1980 & 117.04 & 116.75 & 663 & 14.0 \\
\hline 1981 & 117.21 & 116.65 & 525 & 11.8 \\
\hline 1982 & 117.31 & 116.82 & 677 & 12.6 \\
\hline 1983 & 117.50 & 117.31 & 1,130 & 15.3 \\
\hline 1984 & 117.56 & 117.22 & 1,010 & 14.1 \\
\hline 1985 & 116.29 & 116.12 & 464 & 13.6 \\
\hline 1986 & 117.23 & 116.95 & 829 & 14.3 \\
\hline 1987 & 116.92 & 116.83 & 765 & 15.5 \\
\hline 1988 & 117.14 & 116.85 & 746 & 14.1 \\
\hline 1989 & 117.59 & 117.44 & 1,180 & 15.5 \\
\hline 1990 & 117.53 & 117.21 & 1,010 & 14.2 \\
\hline 1991 & 117.32 & 117.24 & 1,090 & 16.1 \\
\hline 1992 & 117.40 & 117.20 & 1,040 & 15.2 \\
\hline 1993 & 117.44 & 117.28 & 1,110 & 15.5 \\
\hline 1994 & 117.35 & 117.16 & 1,100 & 15.1 \\
\hline 1995 & 117.29 & 117.11 & 992 & 15.2 \\
\hline 1996 & 117.48 & 117.36 & 1,180 & 15.8 \\
\hline 1997 & 117.37 & 117.12 & 979 & 14.7 \\
\hline 1998 & 117.32 & 117.11 & 939 & 15.0 \\
\hline 1999 & 117.11 & 116.86 & 766 & 14.5 \\
\hline 2000 & 117.48 & 117.32 & 1,150 & 15.4 \\
\hline 2001 & 116.76 & 116.66 & 626 & 15.2 \\
\hline 2002 & 117.10 & 116.96 & 873 & 15.4 \\
\hline 2003 & 117.45 & 117.26 & 1,070 & 15.2 \\
\hline 2004 & 116.42 & 116.03 & 387 & 12.0 \\
\hline 2005 & 117.40 & 117.26 & 1,090 & 15.6 \\
\hline 2006 & 117.56 & 116.82 & 616 & 10.6 \\
\hline 2007 & 117.42 & 117.25 & 1,072 & 15.4 \\
\hline 2008 & 117.32 & 117.10 & 979 & 14.9 \\
\hline 2009 & 117.30 & 117.14 & 1,010 & 15.4 \\
\hline
\end{tabular}



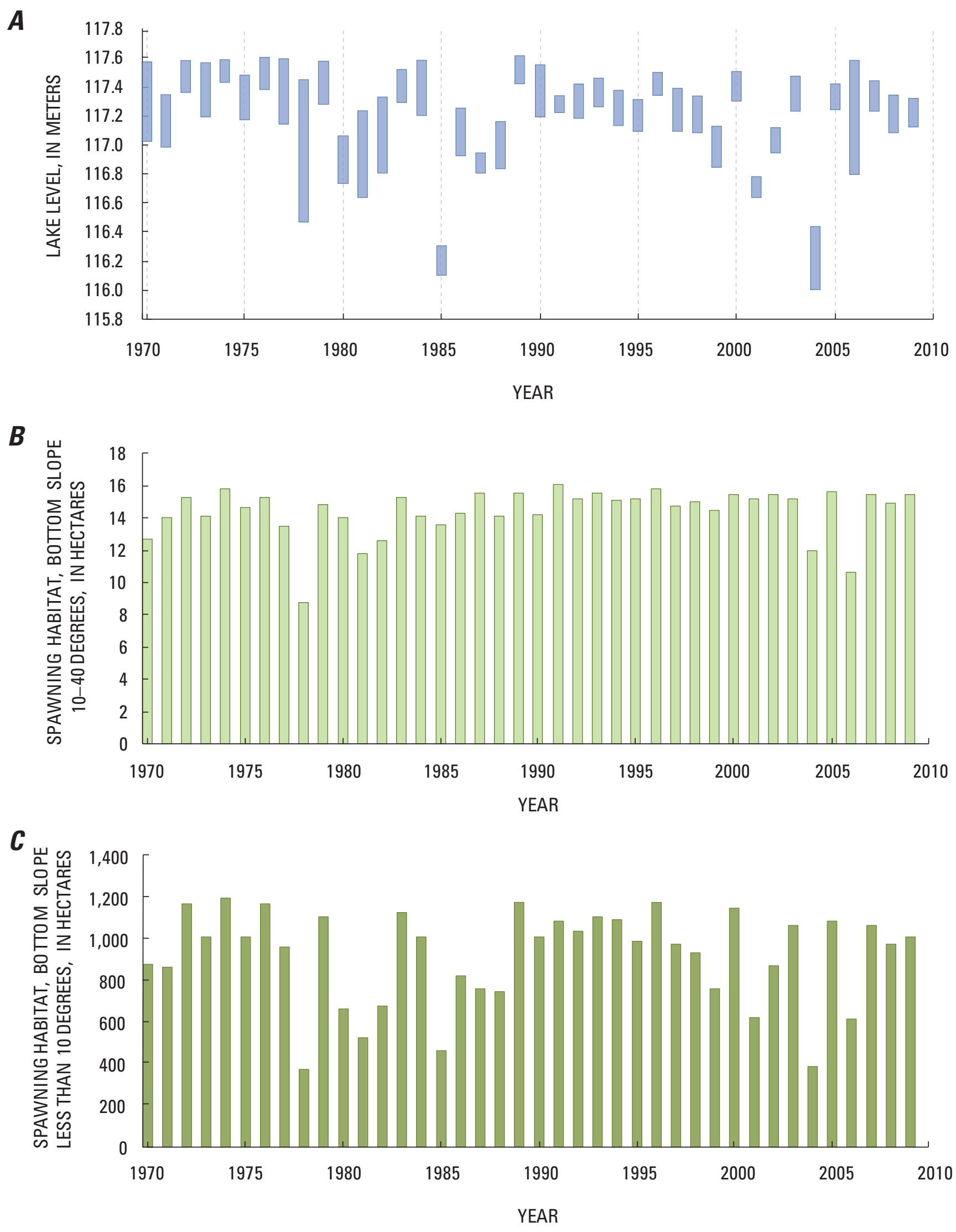

Figure 9. Time series plot of $A$, lake level range and $B, C$, annual historical quantities of habitat during the spawning period (May 20-June 20) in Spednic Lake, 1970-2009. 


\section{References Cited}

Clark, M.E., Rose, K.A., Chandler, J.A., Richter, T.J., Orth, D.J., and Winkle, W.V., 1998, Simulating smallmouth bass reproductive success in reservoirs: Environmental Biology of Fishes, v. 51, no. 2, p. 161-174.

Clark, M.E., Rose, K.A., Chandler, J. A., Richter, T.J., Orth, D.J., and Winkle, W.V., 2008, Water-level fluctuation effects on centrarchid reproductive success in reservoirs: A modeling analysis: North American Journal of Fisheries Management, v. 28, p. 1,138-1,156.

Environment Canada, 2010, Archived Hydrometric Data, accessed May 2010 at http://www.wsc.ec.gc.ca/hydat/H2O/ index_e.cfm? cname $=$ WEBfrmDailyReport_e.cfm

Finlay, K.P., Cyr, H., and Shuter, B.J., 2001, Spatial and temporal variability in water temperatures in the littoral zone of a multibasin lake: Canadian Journal of Fisheries and Aquatic Sciences, v. 58, no. 3, p. 609-619.

Flagg, L.N., 2007, Historical and current distribution and abundance of the anadromous alewife (Alosa psuedoharengus) in the St. Croix River: A report to the State of Maine Atlantic Salmon Commission, May 30, 2007, 20 p.

Goff, G.P., 1985, Environmental influences on annual variation in nest success of smallmouth bass, Micropterus dolomieui, in Long Point Bay, Lake Erie: Environmental Biology of Fishes, v.14, no. 4, p. 303-307.

Helsel, D.R., and Hirsch, R.M., 2002, Statistical methods in water resources: U.S. Geological Survey Techniques of Water-Resources Investigations, book 4, chap. A3, 522 p.

Hunter, L.E., and Smith, G.W., 2001, Morainal banks and the deglaciation of coastal Maine, in Weddle, T.K., and Retelle, M.J., eds., Deglacial history and relative sea-level changes, Northern New England and adjacent Canada: Boulder, Colorado, Geological Society of America Special Paper 351, p. 151-170.

International Joint Commission, 2005, Board discussion paper on alewife in the St. Croix River: International St. Croix River Board, 12 p., accessed May 2010 at http://www.ijc. org/rel/boards/saint/discussionpaper_alewife_oct2005.pdf

MacLean, J.A., Shuter, B.J., Regier, H.A., and MacLeod, J.C., 1981, Temperature and year-class strength of smallmouth bass: Rapports et Proces-verbaux des Reunions, Conseil International Pour L'Exploratin de la Mer, Northwest Atlantic Fisheries Organization, Dartmouth, Nova Scotia, Canada, v. 178, p. 30-40.

Maine Department of Inland Fisheries and Wildlife, 2010, Regional fishing information - Region F (The Penobscot Region) accessed May 2010 at http://www.state.me.us/ifw/ fishing/regional_information/region_f.htm
Marvinney, R.G., and Thompson, W.B., 2000, A geologic history of Maine, in King, V.T. ed., Mineralogy of Maine, volume 2-Mining history, gems, and geology: Maine Geological Survey, Augusta, Maine, p. 1-8.

National Oceanic and Atmospheric Administration, 2002, Climatography of the United States no. 81, monthly station normals of temperature, precipitation, and heating and cooling degree days, 1971-2000: Region 17, Maine, 16 p.

Neves, R.J., 1975, Factors affecting fry production of smallmouth bass (Micropterus dolomieui) in South Branch Lake, Maine: Transactions of the American Fisheries Society, v. 104 , no. $83-87$.

New England Forestry Foundation, 2010, Spednic Lake \& St. Croix River, accessed May 2010 at http://www. newenglandforestry.org/projects/spednicstcroix.asp

Ploskey, G.R., Nestler, J.M., and Bivin, W.M., 1996, Predicting black bass reproductive success from Bull Shoals Reservoir hydrology: American Fisheries Society Symposium.

Randall, A.D., 1996, Mean annual runoff, precipitation, and evapotranspiration in the glaciated northeastern United States, 1951-80: U.S. Geological Survey Open-File Report 96-395, 2 pl.

Randall, A.D., 2001, Hydrogeologic framework of stratifieddrift aquifers in the glaciated northeastern United States: U.S. Geological Survey Professional Paper 1415-B, 179 p. [Plate showing hydrophysiographic regions in the glaciated northeastern United States, scale 1:2,500,000.]

Rejwan, C.N., Collins, C., Brunner, L.J., Shuter, B.J., and Ridgway, M.S., 1999, Tree regression analysis on the nesting habitat of smallmouth bass: Ecology, v. 80, p. 341-348.

Saunders, R., Bozek, M.A., Edwards, C.J., Jennings, M.J. and Newman, S.P., 2002, Habitat features affecting smallmouth bass Micropterus dolomieu nesting success in four northern Wisconsin lakes: American Fisheries Society Symposium, v. 31 , p. 123-134.

Shuter, B. J., MacLean, J.A., Fry, F.E.J., and Regier, H.A., 1980, Stochastic simulation of temperature effects on first-year survival of smallmouth bass: Transactions of the American Fisheries Society, v. 109, p. 1-34.

Shuter, B.J., Wismer, D.A., Regier, H.A., and Matuszek, J.E., 1985, An application of ecological modeling: Impact of thermal effluent on a smallmouth bass population: Transactions of the American Fisheries Society v. 114, p. 631-651.

Thompson, W.B., and Borns, H.W., 1985, Surficial geologic map of Maine: Maine Geological Survey, Department of Conservation, scale 1:5,000,000. 
University of Maine, 2010a, PEARL Database, accessed May 2010 at http://www.pearl.maine.edu/Lake2.

asp? Watercode $=0121$

University of Maine, 2010b, PEARL Database, accessed May 2010 at http://www.pearl.maine.edu/DADataUpload/ BMaps/0121.jpg
U.S. Geological Survey, 2010a, National Water Information System, accessed May 2010 at http://waterdata.usgs.gov/ nwis/nwisman/?site_no $=01018500$ \&agency_cd $=U S G S$

U.S. Geological Survey, 2010b, Annual Data Report: 2009, accessed on May, 2010 at http://wdr.water.usgs.gov/wy2009/ $p d f_{s} / 01018500.2009 . p d f$ 
Prepared by the Pembroke, Lafayette, and Denver Publishing Service Centers.

For more information concerning this report, contact:

Director

U.S. Geological Survey

Maine Water Science Center

196 Whitten Road

Augusta, ME 04330

rmlent@usgs.gov

or visit out Web site at:

http://me.water.usgs.gov 
